\title{
Evaluation of the Progenies from a Cross between Obiaoturugo and Adaka for Evidence of Segregation for Morphological Attributes and Resistance to Major Field Diseases of White Yam (Dioscorea Rotundata Poir)
}

\author{
Nwankwo, I.I.M., Akinbo, O.K., Ezebuiro, V.N., Egbo, G.P., O.D. Okeagu, Ikoro, A.I \\ National Root Crops Research Institute, Umudike, Umuahia, Abia State, Nigeria.
}

\begin{abstract}
A field study was conducted at National Root Crops Research Institute - Umudike Southeast Nigeria to determine evidence of morphological variation, traits that would contribute to tuber yield and response of the progenies to major field diseases. Data were collected on 60 sampled yam progenies out of the 150 progenies evaluated on morphological parameters such as leading vine length, vine diameter, length of leaf, width of leaf, number of leaves, number of lateral vines and severity of major diseases attacking yam cultivars in the field. Data obtained were subjected to statistical analysis using Genstat 5.32 package and Regression analysis was used to determine the morphological characters influencing the tuber yield of the progenies. The result obtained showed significant $(P<0.01)$ variability in the morphological attributes exhibited by the progenies as a result of genetic reshuffling. This was observed in the range for the measurement of each of the morphological characters from minimum to maximum. Also, the variation in the responses of the yam progenies to biotic stresses indicated that there was genetic segregation responsible for the variations exhibited for most of the progenies. Some of the progenies were susceptible, tolerant and resistant to biotic stresses.
\end{abstract}

Keyword: Progenies, A cross, Variation, Morphological characters and Major diseases

\section{INTRODUCTION}

The yam plant is a monocotyledonous and annual herbaceous plant. It has long climbing stems which wind themselves around supports. A single plant produces between one and five tubers of varying shapes, each may weigh up to $5 \mathrm{~kg}$. Certain species produce dioscorine, a toxic alkaloid that is destroyed by cooking. Rich in starch and protein, yam is very popular tropical food. It grows in light, well drained soils and often the most fertile land is set aside for yam cultivation. The yams are the most important staple food crops in West Africa (Ekpe et al, 2005) except for cereals (coursey, 1967, Onwueme, 1978). They also form an important staple food source in tropical countries including East Africa, the Caribbean, South America and Southeast Asia, however, West Africa remains the most important yam producing region of the World (Okonkwo, 1985).

Genetic diversity still exists among economically important yam species. As a result genetic erosion in yam has not until recently been acute (Ngeve, 1999). The two indigenous African yam species: the white yam (Dioscorea rotundata) and yellow yam (Dioscorea cayenensis) are still very diverse, as a result of local adaptation to ecological niches and, perhaps more important, because of consumer preferences for different types, and the wide spread association of yams with cultural and ritual practices (Eastwood and Steele, 1978). However, this variation and the likelihood of maintaining genetic diversity is now threatened by certain factors, such as; the use of preferred cultivars, increased cultivation of less labour -requiring crops such as cassava, maize and rice, and cultivation and adoption of other yam species like the water yam (Dioscorea alata) which are more tolerant to diseases and pests (Ngeve,1999). The white yam (Dioscorea rotundata) is predominantly dioecious with plants bearing either all pistillate (female) or all staminate (male) flowers. The sex separation is not complete since a persisted but low percentage of monoecious plant occurs (Akoroda, 1984). The improvement of the white yam (Dioscorea rotundata) had been limited to the clonal selection (IITA, 1992). However, since the knowledge of floral biology of the white yam (Dioscorea rotundata), the controlled production of hybrid seeds required for genetic improvement of food yams has now been 
possible because of sufficient understanding of the flowering behaviour in relation to practical techniques for artificial pollination (IITA, 1992). Lack of flowering yam plants is identified as a problem and a major obstacle to yam breeding work. Degrass (2000) observed that crossing may be achieved under special isolation, but it is often hampered by irregular flowering behaviour among yam plants and insufficient intensity of flowering. Akoroda (1984) also reported that progress in white yam breeding has been hampered by erratic supply of hybrid seeds due to poor fruit sets as a result of low ratio of flowering male to female plants in the population.

Adequate knowledge of the floral behaviour of the yam plants will prevent genetic barriers to successful hybridization. Sufficient information on floral behaviour of hybrid yam genotypes will enable the breeder to make selection of the genotypes for effective utilization in artificial pollination. It will also provide breeders with enough information that would facilitate the development of efficient and reliable yam plant germplasm that will be a genebank for white yam (Dioscorea rotundata) improvement and enhance the management of pollination in the crop. A sustained high capability flowering yam plant is desirable in breeding population, since the continued use of elite clones as parents in yam hybridization programmes depends to a large extent on whether such clones are flowering and producing seeds (Akoroda et al, 1985).

Flower thrips, the major insects that pollinate yam flowers also usually do a poor job resulting in the abortion of yam female flowers. All these impose restrictions on yam hybridization using conventional techniques (IITA, 2008). With the improved knowledge of the floral biology of yam, controlled hybridization of the yam crop, either through intra-specific (crosses within a species) or inter-specific (crosses between species) pollination can be carried out. This could lead to creation of variability from which selection can be made of yam varieties for various commercial and research purposes.

Despite the importance of yams in the tropics, comparatively little research effort has been devoted to them. Major yam producing countries are poor and often unable to fund meaningful research programmes, especially as yam research is extremely difficult and expensive. The long growth cycle produces only one crop a year and breeding work is often hampered by the irregular sexuality of the yam plants. Therefore, the only variation that exits among cultivated yams is that which was present from the native species. Further, diversity could now be generated from wide crosses between compatible types, which is now possible because of the present state of the knowledge of the floral biology of the yam plant. (Ngeve,1999).

The white yam (Dioscorea rotundata Poir) is a prestigious and most preferred carbohydrate staple for peoples of the tropics particularly in West Africa and the Caribbean (FAO, 1998). Yam production in these areas has been limited by constraints such as pests and diseases and poor food quality of some farmers' varieties. Most farmers do not have access to improved varieties. They depend still on unimproved cultivars that are low yielding and are susceptible to pests, diseases and other abiotic factors. Although more than ten species in this genus have edible tubers which are used for food in various parts of the world, only six species are extensively cultivated in Africa (Onwueme and Sinha, 1999). West Africa is the most important area for yam production in the world (FAO, 1995). Most of the yam tubers produced is consumed locally.

Large collections of accessions with better flowering qualities are in the germplasm which could be manipulated to generate new varieties. Currently, only landraces are in cultivation and this affects yield. The low yield is partly due to limited attempt at breeding the yam crop for higher yield. Again, as a result of population explosion and urban development, hectares of land under agricultural cultivation are shrinking. This suggested reasons for the need for higher yielding genotypes from the available land. Dioscorea rotundata is a species among the 600 species in the family Dioscoreaceae (Daisy, 2000). This indicates the existence of great diversity of this crop which can be utilized for needed improvement (Okoli, 1984). With the progress so far made in the understanding of the reproductive biology of Dioscorea rotundata, the rich varietal diversity within this species can be utilized through intra-and inter-specific hybridization for effective genetic improvement of the Dioscorea species for higher yields. It is believed that selection of resultant hybrid genotypes with higher yield potential, appealing tubers, high flowering intensity and improved morphological characters, will contribute to high yielding genotypes of Dioscorea rotundata for commercial production 
The breeding process to obtain cultivars morphologically different from the parents and resistant to major field diseases such as viruses, fungal and anthracnose can be evaluated at the early stage of the plant. The gene(s) expressing these traits can be identified in the segregating population when segregation has occurred among the progenies derived from a cross between a resistant and a nonresistant parents(Moens et al, 2007).

This study was carried out to find out morphological variations in the progenies, to determine traits that would significantly contribute to tuber yield of the progenies and progenies that are resistant to major field diseases such as viruses, leafspot (fungal) and anthracnose attacking white yam crops in the field. The male parent Adaka was chosen because of its susceptibility to viral and anthracnose diseases while the female Obiaoturugo was chosen because of its hypersensitive reaction to fungal leafspot disease which made this yam plant resistant to this pathogen attacking white yam in the field.

\section{MATERIAls AND MethodS}

Pollens from the male Adaka yam plant were crossed to the female Obiaoturugo yam plant. At maturity, 265 botanical seeds were collected from 422 yam capsules. The winged seeds were winnowed, all seeds unable to withstand the gentle breeze indicated non-functionality and they were removed. The 205 viable botanical seeds were soaked in water and wrapped in moist paper over night and planted in soil medium containing 1:1 soil mixture of topsoil and river sand.

In the following 15 days, 160 of the 205 planted botanical seeds germinated in the growth tray chamber maintained at $28 \pm 1{ }^{\circ} \mathrm{C}, 12$ hours light, and relative humidity of $80 \%$ daily. From the germinated seeds 150 seedlings were selected and planted into poly bags measuring $3 \mathrm{~cm} \times 5 \mathrm{~cm}$ in the Screen house to serve as the testing planting material. At four to five leaves, the yam seedlings are transplanted to the field for further evaluation.

\subsection{Field Experiment}

The field studies were conducted at the western farm of National Root Crops Research Institute (NRCRI) Umudike from 2015 to 2016. Umudike is in the tropical rainforest zone of Nigeria lying between longitude $7^{0} 32^{\prime \prime} \mathrm{E}$ and latitude $5^{0} 29^{\prime \prime} \mathrm{N}$ of the equator on an elevation of 122 metres above sea level (Agrometerological station at NRCRI - Umudike 2008 and 2009).

Umudike has an annual rainfall of $1800 \mathrm{~mm}$ to $2200 \mathrm{~mm}$. The rainy season which commences from March to late October is bi-modal in pattern, and comprises of early rain (March -July) and late rain (August -October) with a dry spell in August and five months of dry season. A part of the dry season is characterized by a cool dry northeastern wind. The air temperature varies from $22^{\circ} \mathrm{C}$ to $32^{\circ} \mathrm{C}$ while the relative humidity varies from $51 \%$ to $87 \%$. The sunshine hours vary from 2.69 to 7.86 hours per day. The dominant soil is acid sandy loam in the ultisol group (FDALR, 1985). The soil was a sand clay (52\% sand, $42 \%$ clay and $6 \%$ silt) with a $\mathrm{pH}$ of 5.8 , an organic matter content of $1.3 \%$ and bases content of $26.8 \mathrm{cmol} / \mathrm{L}$ of $\mathrm{Ca}, 10.1 \mathrm{cmol} / \mathrm{L}$ of $\mathrm{Mg}, 0.25 \mathrm{cmol} / \mathrm{L}$ of $\mathrm{K}, 7.2 \mathrm{mg} / \mathrm{L}$ of $\mathrm{P}, 260 \mathrm{mg} / \mathrm{L}$ of $\mathrm{Fe}$, $5 \mathrm{mg} / \mathrm{L}$ of $\mathrm{Cu}, 1.1 \mathrm{mg} / \mathrm{L}$ of $\mathrm{Zn}$ and $5.5 \mathrm{mg} / \mathrm{L}$ of $\mathrm{Mn}$.

Close the site for setting up of the experiment was planted Dioscorea alata, Manihot esculenta Crantz and Telfaira occidentalis to ensure high presence of viral, fungal and anthracnose diseases.

One hundred and fifty (150) seedlings from the cross between Obiaoturugo and Adaka were established in three plots. Each plot was made up of a population of 50 yam seedlings with

planting distant of $30 \mathrm{~cm}$ between plants and $100 \mathrm{~cm}$ between rows in a plot size of $5 \mathrm{~m}$ by $10 \mathrm{~m}$. This gave a plant population of 50 plants per plot and by 3 blocks which gave a total of 150 yam seedlings. N.P.K Compound fertilizer was applied to the soil two weeks after seedlings were transplanted to the field.

Eight weeks after planting and every eight weeks of the plant growth in the field, all the 50 yam seedlings per plot and in the 3 blocks were evaluated to determine the severity of the field major diseases attacking yam plants in the field. During the growth stage, twenty diagonally selected yam 
plants were sampled and tagged in all the three blocks to determine the morphological parameters such as leading vine length, vine diameter, length of leaf, width of leaf, number of lateral vines and number of leaves. The leaves were measured each from base and at the middle in all the 20 yam plant seedlings and averaged to determine the mean. At time of harvest, the length and diameter of tuber in $\mathrm{cm}$ were measured in all the 20 yam seedlings in each plot and averaged by the three blocks to obtain the mean.

\begin{tabular}{|l|c|c|c|l|c|c|c|c|c|}
\hline \hline 1 & 2 & 3 & 4 & 5 & 6 & 7 & 8 & 9 & 10 \\
\hline 11 & 12 & 13 & 14 & 15 & 16 & 17 & 18 & 19 & 20 \\
\hline 21 & 22 & 23 & 24 & 25 & 26 & 27 & 28 & 29 & 30 \\
\hline 31 & 32 & 33 & 34 & 35 & 36 & 37 & 38 & 39 & 40 \\
\hline 41 & 42 & 43 & 44 & 45 & 46 & 47 & 48 & 49 & 50 \\
\hline
\end{tabular}

BLOCK 1

\begin{tabular}{|c|c|c|c|c|c|c|c|c|c|}
\hline 10 & 9 & 8 & 7 & 6 & 5 & 4 & 3 & 2 & 1 \\
\hline 20 & 19 & 18 & 17 & 16 & 15 & 14 & 13 & 12 & 11 \\
\hline 30 & 29 & 28 & 27 & 26 & 25 & 24 & 23 & 22 & 21 \\
\hline 40 & 39 & 38 & 37 & 36 & 35 & 34 & 33 & 32 & 31 \\
\hline 50 & 49 & 48 & 47 & 46 & 45 & 44 & 43 & 42 & 41 \\
\hline
\end{tabular}

BLOCK 2

\begin{tabular}{|c|c|c|c|c|c|c|c|c|c|}
\hline 1 & 2 & 3 & 4 & 5 & 6 & 7 & 8 & 9 & 10 \\
\hline 11 & 12 & 13 & 14 & 15 & 16 & 17 & 18 & 19 & 20 \\
\hline 21 & 22 & 23 & 24 & 25 & 26 & 27 & 28 & 29 & 30 \\
\hline 31 & 32 & 33 & 34 & 35 & 36 & 37 & 38 & 39 & 40 \\
\hline 41 & 42 & 43 & 44 & 45 & 46 & 47 & 48 & 49 & 50 \\
\hline
\end{tabular}

BLOCK 3

Sampling of the tagged plants for morphological data collection;

For plant $1=\underline{1+10+1}$

$$
3
$$

For plant $2=\underline{2+9+2}$

$$
3
$$

for plant $3=\underline{13+18+13}$

$$
3
$$

for plant $4=\underline{14+17+14}$

$$
3
$$

For plant $20=\underline{10+1+10}$

$$
3
$$

Disease severity was evaluated in all the yam plants. The following parameters were used; Calculation of total functional leaves, number of leaves affected and yam plant affected. The disease severity index was obtained by using severity scoring scale of 1 to 5 . Where $1=$ no symptom, $2=$ symptom very mild, $3=$ symptom moderate, $4=$ symptom severe, $5=$ symptom very severe. The percentage number of leaves affected per each scale/index was calculated as: The numbers of leaves in each grade of infection divide by the sum of the evaluated functional leaves on the plant in question.

\subsection{Data Analysis}

All data collected were subjected to analyses of variances using the Genstat 5.32 statistical packages. Significant means were separated using standard error of difference. The Multiple regression analysis 
Evaluation of the Progenies from a Cross between Obiaoturugo and Adaka for Evidence of Segregation for Morphological Attributes and Resistance to Major Field Diseases of White Yam (Dioscorea Rotundata Poir)

was used to predict the contribution of the morphological traits to the yield of the seedlings based on their morphological traits performance. $\mathrm{Y}=\mathrm{a}+\mathrm{bX} \mathrm{X}_{1}+\mathrm{bX} \mathrm{X}_{2}+\mathrm{bX} \mathrm{X}_{3}+\mathrm{bX} \mathrm{X}_{4}+\mathrm{bX} \mathrm{X}_{5}+\mathrm{bX} \mathrm{X}_{6}+\ldots \mathrm{bXn}$

\section{RESULT AND DisCUSSION}

The morphological plant characteristics of the tested yam plant progenies of the cross between Obiaoturugo and Adaka is presented on Table 1.

Table1. The morphological plant characteristics of the tested yam plant progenies of the cross between Obiaoturugo and Adaka

\begin{tabular}{|c|c|c|c|c|c|c|c|c|c|c|}
\hline $\begin{array}{c}\text { Plant } \\
\text { sampled }\end{array}$ & $\begin{array}{c}\text { Leading } \\
\text { vine } \\
\text { length } \\
\text { per plant } \\
\text { (m) }\end{array}$ & $\begin{array}{c}\text { Vine } \\
\text { diameter } \\
\text { per plant } \\
(\mathrm{mm})\end{array}$ & $\begin{array}{c}\text { Number } \\
\text { of } \\
\text { lateral } \\
\text { vines } \\
\text { per plant }\end{array}$ & $\begin{array}{l}\text { Leaf } \\
\text { length } \\
(\mathrm{cm})\end{array}$ & $\begin{array}{c}\text { Leaf } \\
\text { width } \\
(\mathrm{cm})\end{array}$ & $\begin{array}{c}\text { Number of } \\
\text { leaves per } \\
\text { plant }\end{array}$ & \begin{tabular}{|c|} 
Tuber \\
weight \\
per plant \\
$(\mathrm{g})$
\end{tabular} & $\begin{array}{c}\text { Tuber } \\
\text { length } \\
\text { per } \\
\text { plant } \\
(\mathrm{cm})\end{array}$ & $\begin{array}{c}\text { Tuber } \\
\text { diameter } \\
\text { per } \\
\text { plant } \\
(\mathrm{cm})\end{array}$ & $\begin{array}{l}\text { Tuber } \\
\text { surface } \\
\text { texture }\end{array}$ \\
\hline 1 & 1.0 & 0.03 & 12.1 & 5.0 & 4.0 & 202.6 & 10.8 & 4.0 & 3.1 & 1 \\
\hline 2 & 1.5 & 0.02 & 15.2 & 5.1 & 4.0 & 256.4 & 13.8 & 5.0 & 3.2 & 1 \\
\hline 3 & 1.2 & 0.02 & 20.4 & 8.2 & 3.0 & 255.6 & 15.0 & 3.0 & 2.1 & 1 \\
\hline 4 & 1.8 & 0.03 & 35.4 & 7.0 & 4.0 & 222.5 & 20.7 & 3.2 & 3.2 & 2 \\
\hline 5 & 1.7 & 0.02 & 6.5 & 6.4 & 5.1 & 311.2 & 35.2 & 4.3 & 2.2 & 1 \\
\hline 6 & 1.9 & 0.04 & 18.3 & 8.0 & 4.0 & 235.3 & 16.6 & 3.4 & 3.1 & 1 \\
\hline 7 & 1.4 & 2.00 & 23.2 & 4.5 & 4.3 & 231.3 & 18.0 & 4.4 & 3.1 & 1 \\
\hline 8 & 1.3 & 0.03 & 17.2 & 8.0 & 4.1 & 200.5 & 20.4 & 4.1 & 2.2 & 2 \\
\hline 9 & 1.6 & 0.04 & 11.4 & 7.3 & 3.2 & 245.2 & 23.0 & 4.2 & 2.5 & 2 \\
\hline 10 & 1.1 & 0.05 & 19.5 & 6.2 & 3.1 & 368.6 & 34.1 & 4.1 & 2.4 & 1 \\
\hline 11 & 1.9 & 0.03 & 33.6 & 5.2 & 4.0 & 305.7 & 33.2 & 4.3 & 3.3 & 1 \\
\hline 12 & 2.2 & 0.06 & 10.5 & 6.0 & 3.5 & 243.5 & 19.3 & 4.6 & 2.3 & 2 \\
\hline 13 & 1.8 & 0.03 & 15.2 & 7.1 & 4.2 & 252.6 & 28.0 & 4.8 & 3.4 & 1 \\
\hline 14 & 1.5 & 0.04 & 13.0 & 8.2 & 4.3 & 272.0 & 15.4 & 4.2 & 2.4 & 1 \\
\hline 15 & 1.4 & 0.02 & 27.1 & 5.2 & 4.1 & 221.8 & 18.5 & 3.8 & 3.4 & 1 \\
\hline 16 & 2.3 & 0.02 & 31.2 & 6.1 & 4.2 & 248.9 & 20.5 & 3.0 & 3.1 & 1 \\
\hline 17 & 1.6 & 0.03 & 29.6 & 8.2 & 3.7 & 341.0 & 30.2 & 4.1 & 2.6 & 2 \\
\hline 18 & 1.8 & 0.04 & 14.4 & 7.3 & 3.4 & 344.6 & 32.3 & 3.6 & 3.2 & 1 \\
\hline 19 & 1.5 & 0.05 & 6.8 & 6.2 & 4.1 & 281.5 & 29.2 & 3.2 & 3.4 & 2 \\
\hline 20 & 1.3 & 0.02 & 17.1 & 6.5 & 3.7 & 312.3 & 33.4 & 4.2 & 3.2 & 2 \\
\hline Mean & 1.59 & 0.13 & 18.9 & 5.95 & 3.9 & 256.09 & 23.4 & 4.0 & 2.87 & - \\
\hline Range & $1.0-2.3$ & 0.02-0.06 & $6.2-35.4$ & 4.5-8.2 & 3.0-5.1 & $\begin{array}{l}200.5- \\
368.6\end{array}$ & $10.8-35.2$ & 3.0-4.8 & 2.1-3.4 & - \\
\hline SED & 0.31 & 0.02 & 9.6 & 0.2 & 0.01 & 16.4 & 5.02 & 0.4 & 0.2 & - \\
\hline Sig. level & $\mathrm{P}<0.01$ & $\mathrm{P}<0.01$ & $\mathrm{P}<0.01$ & $\mathrm{P}<0.01$ & $\mathrm{P}<0.01$ & $\mathrm{P}<0.01$ & $\mathrm{P}<0.01$ & $\mathrm{P}<0.01$ & $\mathrm{P}<0.01$ & $\mathrm{P}<0.01$ \\
\hline
\end{tabular}

Note: Smooth=1, Rough either thorny or hairy $=2$.

\section{1.rogenies Morphological Attributes}

The morphological attributes of the progenies such as leading vine length, Vine diameter, length of lateral vine, Leaf length, Leaf width, Tuber weight, Tuber length, Tuber diameter and Tuber surface texture differed significantly $(\mathrm{P}<0.01)$ among the tested progenies as discussed below.

\subsubsection{Length of Leading Vines}

The high significant $(\mathrm{P}<0.01)$ variation in the length of leading vines indicated that leading vine lengths varied from 1.0 to $2.3 \mathrm{~m}$ with mean of $1.59 \mathrm{~m}$. The variation in the leading vine lengths under the same environment was an evidence of genetic variability exhibited by the progenies derived from the cross between Obiaoturugo and Adaka. The range in the leading vine length suggested that some of the yam plants would be genetically short an indication of bushy type of yam plant, medium and while some of the yam plants would be very tall requiring stakes to support the leading vines to perform their genetic trait of elongation. This showed that in developing this type of yam varieties, supporting the yam plant with stakes would be included in the cropping package for the yam cultivation. 


\subsubsection{Vine Diameter}

This measures the thickness of the vine. Vine diameter variability was observed among the progenies tested. The high significant $(\mathrm{P}<0.01)$ differences in the vine diameter ranged from 0.02 to as thick as $.05 \mathrm{~mm}$ with mean of $0.13 \mathrm{~mm}$. This was an indication of genetic variability among the tested progenies from the cross. This evidence could be used in differentiating the yam varieties from each other. Some of the yam plants would have thin vines which imply that if such yam plant succeeded to be selected for yam cultivation, most of them would be prone to damages through cutting and breakage during farming operations like weed control or fertilizer applications. Also, the tiny vine diameter may affect the amount of photosynthate that goes down to the sink/tuber and this would lead to low tuber yield. However, thick vine diameter gives the yam plant strong vigour, an indication that the yam plant would yield highly.

\subsubsection{Number of Lateral Vines}

The variability in the number of lateral vines produced by the hybrid progenies was significantly high $(\mathrm{P}<0.01)$. Number of lateral vines ranged from 6.2 to as high as 35.0 per plant. This showed that some yam plant would genetically have few lateral vines while others would produce profuse lateral vines. Number of lateral vines could be used as traits for distinguishing yam plants. Lateral vines assist the yam plant to evenly spread out the leaves for more photosynthesis which invariably lead to high tuber yield. However, profuse lateral vines keeps the farmer always training, trailing and tendering the vines to climb on stake materials. Also, yam plants with profuse lateral vines tend to cling on other plants intercropped with the yam plant and reduce free movement inside the farm especially during farm inspections and other farm operations. Little or no lateral vines make the yam plant compact and less labour is required for tendering the vines on stakes in addition of easing free movement of operations in the yam farm.

\subsubsection{Leaf Length}

There were high significant $(\mathrm{P}<0.01)$ variation in the length of leaves as observed among the leaves produced by the yam plant progenies. The leaf lengths varied from 4.5 to $8.2 \mathrm{~cm}$ with mean of $5.95 \mathrm{~cm}$. This variation indicated that some yam plants would have leaves which are long and some with leaves which are short. This indicated evidence of genetic variability in leaves of the progenies which could be used to individualize the yam plants.

\subsubsection{Leaf Width}

The leaves of the yam progenies varied from 3.0 to $5.1 \mathrm{~cm}$ with mean of $3.9 \mathrm{~cm}$. This variation was significantly high $(\mathrm{P}<0.01)$ and could be used as evidence of genetic variability which could be used for distinguishing one variety from another. Large leaf width contributes to the plant's leaf area which is a large surface area for photosynthesis.

\subsubsection{Number of Leaves}

Number of leaves per plant varied significantly $(\mathrm{P}<0.01)$ among the yam plant progenies. Number of leaves ranged from 200.5 to as many as 368.6 with mean of 256.1 leaves. This indicated evidence of genetic variation which could be used in yam plants distinction. Large number of leaves is an indication of high photosynthetic efficiency which lead to high tuber yield. Yam plants with high number of leaves always yield highly. High number of leaves is also an indicator of high vigour. Yam plant with high number of leaves use such genetic trait in smoldering weeds in any "weed crop organization".

\subsubsection{Tuber Weight Per Plant}

High significant $(\mathrm{P}<0.01)$ variation exist in the tuber weight exhibited by the progenies of the yam plant. The tuber weight per plant varied from $10.8 \mathrm{~g}$ to as high as $35.2 \mathrm{~g}$ with mean of $23.4 \mathrm{~g}$. This was evidence of genetic variation among the yam plants developed from the same parents. Tuber weight could be used in distinguishing yam genotypes that are high or low yielding and it is an index for selection of genotypes for further evaluation.

\subsubsection{Tuber Length Per Plant}

The progenies produced high significant $(\mathrm{P}<0.01)$ variation in tuber length. The least tuber length was $3.0 \mathrm{~cm}$ and the longest was $5.0 \mathrm{~cm}$ with mean of $4.0 \mathrm{~cm}$. This variation in tuber length was evidence of genetic variation developed from yam plants from the same parents. Tubers with short length contribute to ease of harvest in yam cultivation. 
Evaluation of the Progenies from a Cross between Obiaoturugo and Adaka for Evidence of Segregation for Morphological Attributes and Resistance to Major Field Diseases of White Yam (Dioscorea Rotundata Poir)

\subsubsection{Tuber Diameter}

The diameter of the tubers from the yam plants ranged from 2.1 to as wide as $3.4 \mathrm{~cm}$ with mean of $2.87 \mathrm{~cm}$. This indicated that high significant $(\mathrm{P}<0.01)$ variation in the width of the tubers could be used to distinguished the yam plants. Yam progenies with wide tuber is an evidence of high photosynthetic efficiency for high tuber yield.

\subsubsection{Tuber Surface Texture}

There were significant $(\mathrm{P}<0.01)$ variations in tuber surface texture. The surface texture of most of yam tubers produced by the progenies were smooth, hairy and thorny which was an evidence of genetic variation which could be used to distinguished the yam progenies.

\subsubsection{Contribution of Morphological Traits to Tuber Yield of the Progenies}

The variability in the morphological traits of the yam progenies contributed positively or negatively to tuber yield of the yam plant progenies. The traits that contributed to tuber yield of the progenies are presented in Table 2 .

Table 2. Regression analysis for determining morphological traits contributing to tuber yield of the progenies evaluated

\begin{tabular}{|c|c|c|c|c|c|}
\hline & & B-coefficient & Standard error & t-stat & P-value \\
\hline Traits & Intercept & & & & \\
\hline & 157821.9 & & & & \\
\hline Leading vine length per plant (m) & & -72405.4 & 235077.5 & 0.0314 & 0.8867 \\
\hline Vine diameter per plant (mm) & & 55342.4 & 21784 & 0.0349 & 0.4853 \\
\hline Number of lateral vines per plant & & 912.67 & 432784.5 & 1.8560 & 0.0086 \\
\hline Leaf length (cm) & & 74497.05 & 1897.71 & 5.2266 & 0.5342 \\
\hline Leaf width (cm) & & 2345.56 & 26732.34 & 0.4217 & 0.1247 \\
\hline Number of leaves & & 1468.02 & 11232.12 & 0.2753 & 0.0014 \\
\hline Tuber length per plant (cm) & & 6285.09 & 2431.23 & 0.8635 & 0.2543 \\
\hline Tuber diameter per plant (cm) & & 2126.67 & 1283.98 & 1.7543 & 0.1634 \\
\hline Tuber surface texture & & 3462.78 & 13487.12 & 1.2307 & 0.1963 \\
\hline
\end{tabular}

The leading vine length associated negatively with tuber weights of the progenies. This means that the shorter the leading vine length, the higher the yield. This could implied that the photosynthate produced by the leaves were not utilized for growth only, but were stored in the tuber for future use. For each tuber yield by the progenies, the formula predicted that the vine diameter contributed a significant $(\mathrm{P}<0.05)$ amount of 55342.4 for that first yield. The number of lateral vines produced by the progenies in the first year contributed additional high significant $(\mathrm{P}<0.01)$ amount of 912.67 to the tuber yield of the progenies.

Each tuber yield increase made by the progenies for the first year is predicted that leaf length and leaf width contributed what worth additional significant $(\mathrm{P}<0.05)$ amounts of 74497.05 and 2345.56 respectively. Number of leaves produced by the progenies was predicted to contribute significantly $(\mathrm{P}<0.01)$ the amount that worth 1468.02 to the tuber yield of the progenies that very first year. The prediction made by the formula indicated that tuber length and tuber diameter made significant contributions worth of 6285.09 and 2126.67 respectively.

The effect of the nine traits of the progenies measured as observed from the equation indicated that the coefficients of the optimal linear formula for predicting the tuber yield of the progenies that first year will make approximately: $\mathrm{Y}=157821.9$ (Constant) -72405.4 x Leading vine length per plant $(\mathrm{m})+55342.4 \mathrm{x}$ Vine diameter per plant $(\mathrm{mm})+912.67 \mathrm{x}$ Number of lateral vines per plant +74497.05 $x$ Leaf length $(\mathrm{cm})+2345.56$ x Leaf width $(\mathrm{cm})+1468.02 \times$ Number of leaves $+6285.09 \times$ Tuber length per plant $(\mathrm{cm})+2126.67 \mathrm{x}$ Tuber diameter per plant $(\mathrm{cm})+3462.78$ x Tuber surface texture. This showed that for yield increase of the progenies, all agronomical packages to allow the traits fully express their genetic potential must be put in place. Such packages include weeding regime, right type and amount of fertilizers, staking, insect pests' control, planting at the right time, planting spacing and others. 


\subsection{Biotic Stresses}

The response of the foliage of the yam progenies and the yam plant progenies to biotic stresses are presented in Table 3.

Table3. Response of the foliage of the yam progenies and the progeny yam plants to biotic stresses

\begin{tabular}{|c|c|c|c|c|c|c|c|c|c|c|c|c|c|c|c|c|c|c|}
\hline & \multicolumn{6}{|c|}{ Viruses } & \multicolumn{6}{|c|}{ Anthracnose } & \multicolumn{6}{|c|}{ Leaf spot } \\
\hline $\begin{array}{c}\text { Numb } \\
\text { er of } \\
\text { Plants } \\
\text { sampl } \\
\text { ed }\end{array}$ & $\begin{array}{c}\text { Incidenc } \\
\text { es }\end{array}$ & $\begin{array}{c}\text { severi } \\
\text { ty }\end{array}$ & $\begin{array}{c}\text { Number } \\
\text { of } \\
\text { function } \\
\text { al } \\
\text { leaves }\end{array}$ & \begin{tabular}{|c} 
Numb \\
er of \\
affect \\
ed \\
leaves
\end{tabular} & $\begin{array}{c}\% \text { no. } \\
\text { of } \\
\text { leaves } \\
\text { affect } \\
\text { ed }\end{array}$ & $\begin{array}{c}\% \text { no. } \\
\text { of } \\
\text { plants } \\
\text { affect } \\
\text { ed }\end{array}$ & $\begin{array}{c}\text { Incidenc } \\
\text { es }\end{array}$ & $\begin{array}{c}\text { severi } \\
\text { ty }\end{array}$ & $\begin{array}{c}\text { Number } \\
\text { of } \\
\text { function } \\
\text { al } \\
\text { leaves }\end{array}$ & $\begin{array}{l}\text { Numb } \\
\text { er of } \\
\text { affect } \\
\text { ed } \\
\text { leaves }\end{array}$ & $\begin{array}{c}\% \text { no. } \\
\text { of } \\
\text { leaves } \\
\text { affect } \\
\text { ed }\end{array}$ & $\begin{array}{c}\% \text { no. } \\
\text { of } \\
\text { plants } \\
\text { affect } \\
\text { ed }\end{array}$ & $\begin{array}{c}\text { Incidenc } \\
\text { es }\end{array}$ & $\begin{array}{c}\text { severi } \\
\text { ty }\end{array}$ & $\begin{array}{c}\text { Number } \\
\text { of } \\
\text { function } \\
\text { al } \\
\text { leaves }\end{array}$ & $\begin{array}{c}\text { Numb } \\
\text { er of } \\
\text { affect } \\
\text { ed } \\
\text { leaves }\end{array}$ & $\begin{array}{c}\% \text { no. } \\
\text { of } \\
\text { leaves } \\
\text { affect } \\
\text { ed }\end{array}$ & $\begin{array}{c}\% \text { no. } \\
\text { of } \\
\text { plants } \\
\text { affect } \\
\text { ed }\end{array}$ \\
\hline 150 & 5 & 4 & 1342 & 1284 & 95.7 & 3.3 & 150 & 1 & 33901 & 0.0 & 0.0 & 100.0 & 150 & 1 & 33901 & 0.0 & 0.0 & 0.0 \\
\hline 150 & 16 & 3 & 5270 & 2174 & 41.2 & 4.0 & 150 & 1 & 33901 & 0.0 & 0.0 & 100.0 & 150 & 1 & 33901 & 0.0 & 0.0 & 0.0 \\
\hline 150 & 3 & 2 & 912 & 45 & 4.9 & 1.3 & 150 & 1 & 33901 & 0.0 & 0.0 & 100.0 & 150 & 1 & 33901 & 0.0 & 0.0 & 0.0 \\
\hline 150 & 126 & 1 & 26377 & 0.0 & 0.0 & 84.0 & 150 & 1 & 33901 & 0.0 & 0.0 & 100.0 & 3 & 3 & 33901 & 802 & 2.4 & 2.0 \\
\hline
\end{tabular}

\subsubsection{Virus Diseases}

The result of the response of the foliage of the yam progenies and the yam plant progenies evaluated indicated that virus diseases severely (Score 4) attacked five out of the 150 yam progenies visually evaluated. Out of 1342 functional leaves produced by the five yam progenies, 1284 leaves represented by $95.7 \%$ were severely affected. This represented $3.3 \%$ of the number of yam progenies attacked by virus diseases. This showed that genetically some of the yam progenies would be susceptible to viral infection and should not be selected for further evaluation (Table 3).

The severity rating of score 3 showed that 16 yam plant progenies out of 150 progenies evaluated were moderately (Scored 3) attacked. This was indicated in the number of leaves affected. Out of the 5270 functional leaves, 2174 leaves from 16 yam plant progenies represented by $41.2 \%$ were moderately (Scored 3) attacked by virus diseases. This represented $4.0 \%$ of the yam plant progenies affected. This group of yam plant progenies could easily breakdown to virus infection. Selecting them for further evaluation is risky and would only lead in propagating the disease since virus disease is systemic.

Of the 150 yam progenies, three yam plant progenies were mildly (Score 2) attacked by virus diseases. Of all the 912 functional leaves produced by the yam progenies 45 leaves represented by $4.9 \%$ were affected and this represented $1.3 \%$ of the yam progenies evaluated. This group of yam plant could be tolerant to yam virus diseases attacking yam plants in the field. It was observed that 126 yam progenies out of 150 progenies evaluated were not attacked by viruses (Score 1). This was observed on the 26377 functional leaves produced by the yam progenies, and this accounted for $84.0 \%$ of the yam progenies evaluated. This group of yam plants would be resistant to yam virus diseases and should be selected for further evaluation (Table 3)

\subsubsection{Anthracnose Disease}

All the 150 yam progenies evaluated had the visual score of clean leaves (Score 1) which indicated that the progenies were not affected by anthracnose disease. This was observed on the 33901 functional leaves produced by the 150 yam progenies, none showed evidence of anthracnose infection. This indicated that the progenies evaluated were anthracnose resistant in the field. Number of leaves and percent number of progenies affected were zero and zero percentage respectively (Table 3).

\subsubsection{Leaf Spot Disease}

Leafspot disease moderately (Score 3) affected three yam progenies out of the 150 yam progenies evaluated. The fungal leafspot infection attacked 802 leaves out of the 33901 functional leaves produced by the yam progenies. The moderate (Score 3) infection was evidence of susceptibility of the three yam plant progenies to leafspot disease. This accounted for $2.4 \%$ of the functional leaves affected and $2.0 \%$ of the number of plant evaluated. The removal of these plants could be the best option for early control of this disease.

\section{Discussion}

The variability in the morphological attributes as exhibited by the hybrid yam progenies from the cross between Obiaoturugo and Adaka is evidence of genetic variability that resulted in gene 
shuffling. This is because cross breeding two heterozygous genotypes lead to the development of segregation for many traits as a result of large number of heterozygous genes (Jawarha, 2006). Genetic variability studies are important in the selection of hybrid progenies for further evaluation. This is because crop improvement importance depends upon the magnitude of genetic variability in the population (Binks and Gowen 1997). According to Laurie et al, (1999), yield in any crop is most important especially to the farmers. However, the genetic variability in the yield of crops is contributed by plants' characters and environments. This confirmed the observation of Agbo and Obi (2005) who in their work on rice reported that genetic variability existed in the yield and agronomic characters of the rice breeding lines evaluated. Yield of crops can be related to many traits since only few traits can be improved at a time during a breeding cycle, it becomes necessary to select few traits among those that have impact on yield. They also have a range of other important traits which allow growers and users to choose the variety that best suits their specific needs or preferences, such as short leading vine length, long leading vine length (1.0 to $2.3 \mathrm{~m})$, small vine diameter, wide vine diameter (0.02 to $0.06 \mathrm{~mm}$ ), few lateral vine, profuse lateral vine 6.2 to 35.4 lateral vines), short Leaf length and long leaf length 4.5 to $8.2 \mathrm{~cm}$ ), wide Leaf width, small leaf width $(3.0$ to $5.1 \mathrm{~cm})$, Tuber weight 1.5 to $35.2 \mathrm{~g}$ ), short tuber length and long tuber length 3.0 to $4.8 \mathrm{~cm})$, Tuber diameter ( 2.1 to $3.4 \mathrm{~mm}$ ), Tuber surface texture $1=$ smooth, $2=$ rough) and other morphological characteristics (Table 1). Further evaluation and release of these varieties will give farmers a wider range of superior varieties to choose from and will improve their farming systems, food security and income generation. The long leading vine length 1.0 to $2.3 \mathrm{~m}$ and above requires staking to support the weight of the vines and to expose the leaves for maximum sunlight absorption which will lead to high yield which is the major objective of the farmer. The stakes will also support the lateral vines to spread out the leaves thereby increasing the surface leave area of the yam plant. In areas with very limited staking materials such as savanna regions, short leading vine lengths are ideal for planting since the vines and leaves would be resting on the raised mounds used for planting the yam. The short tuber lengths are ideal yam plants in stony and hard soil areas where the tubers are not required to penetrate the hard soil. This would make it easier to harvest the crop. The smooth tuber surface texture increases the market value for the tuber. It also increases the ease of processing for food. The thorny tubers act as protection in areas with foraging animals Onwueme and Sinha, 1999). This variability in the yam plant could be selected for adaptation in various areas and in various farming systems.

The remarkable differences observed among the yam progenies used in this study for the various tuber morphological characters that were measured indicated that segregation took place during hybridization due to gene shuffling (Jawahar, 2006). In a breeding programme aimed at developing yam varieties with morphological variations, these progenies would be excellent to be used as parents that would be included in the crossing block to further transfer their valuable traits for improvement of the yam crop. Among the segregating generations, following such hybridization, there is high probability of selecting progenies that carry the desired traits. The developed progenies in this study have a range of important traits which would allow growers and users to choose the variety that best suits their needs or preferences. Such traits include smooth surface skin texture that appeals to the eyes and increase the marketing value and income generation for the farmers who are the end users.

Yam genotypes for inclusion into the germplasm should be selected from progenies recently developed from the botanical seeds than from the landraces which their flowering intensity decreases as the years go by. The current study also showed that the variability that exists among the traits considered contributed significantly to tuber yield. Each tuber yield increase made by the progenies for the first year is predicted based on the significant $(\mathrm{P}<0.01)$ morphological traits contributions (Table 2). These traits should be enhanced with improved agronomic packages to fully express their genetic potential since poor environment puts a ceiling on the expression of genetic variation of a trait (Nwankwo, 2015).

The differential responses of the foliage of the hybrid yam progenies to biotic stress indicated that there were genetic segregation responsible for the variation (Table 3). Some of the progenies were susceptible, tolerant and resistant to the field diseases attacking yam crop in the field. 


\section{Conclusion}

The study indicated evidence of genetic segregation among the progenies from the same parents. Further evaluation of these progenies would lead to the development and selection of genotypes that are superior in one or more characters to the existing ones. The yield of any crop today is not the best yield. There is the need to continue to cross breed crops to genetically enhance and to select what seems the best variant. There is also the need for the breeders and growers to be on the lookout for any variation which might have potential benefits (Daniells and Smith, 1993). Growers need to exploit variations for the benefits they may bring. As to whether the progenies will be superior cultivars, the answer will depend on local environmental circumstances and crop management practices. The segregating progenies that resulted from the cross between Obiaoturugo and Adaka that were screened under natural conditions for resistance to multiple diseases indicated that segregating progenies developed genetic variability in their response to disease reactions. These progenies will be further evaluated for yield and other agronomic characteristics. Daniells (2000) has pointed out that there is no perfect variety, that each has its own set of advantages and disadvantages. Yam growers must find out what is best for them.

\section{REFERENCES}

[1] Agbo,G.U and Obi, I.U (2005).Genetic variability of the yield and agronomic characters of breeding lines of rice (Oryza sativa (L) in Nsukka. In: Uguru, M.I., Iroegbu, C.U and Ejere, V.C. (eds.). Genetics and Sustainable Agriculture. Proceedings of the 30th Ann. Conf. of Gen. Soc. of Nig., Nsukka, 5th-9th Sept., 2005. Pp 193-199.

[2] Akoroda, M.O. (1984). Long term storage of yam pollen Scientia Hortie 20:255 - 230.

[3] Akoroda, M.O, Wilson, J.E and Chheda, H.R. (1985). Artificial pollination, pollen viability and storage in white yam. Tropical A Root Crops Research strategies for the 1980's. In Dev. Centre 163c Ottawa Canada pp 189 - 194.

[4] Binks, R.H and S.R. Gowen (1997). Early screening of banana and plantain varieties for resistant to Radopholus similis. International Journal of Nematology 7: 57-61

[5] Coursey D.C (1987). The role of yams in West Africa food economies, Tropical development and Resea rch Institute. Cali. Columbia p- 32.

[6] Daisy, E.K (2000) Root Crops, Tropical developments and Research Institute. Journal of Science. Volume 6 pp 36-40.

[7] Daniells, J.W.(2000). Which banana variety should I grow? Informusa 9 (1):31-33

[8] (Daniells, J.W and M.K. Smith, 1993). Somatic mutations of banana - their stability and potential. Pp 162 in Proceedings of the International symposium on recent developments in banana cultivation technology (R.V Valmayor, S.C. Hwang. R. Ploetz, S.W.LEE and N.V. Roa, eds.). 14 -18 December 1992, Los Banos, Philippines. INIBAP/ASPNET.

[9] Degrass, L. (1993) The Yam. A Tropical Crop Macmillian Press Ltd London p 408.

[10] Degrass (2000) The yam. A Tropical Root Crop. The Technical center for Agricultural and Rural cooperation (CTA). The Macmillian Press London pp 408.

[11] Eastwood, T. F and Steele, J. P (1978). Agricultural Biodiversity. Biodiversity International publication 1978. p21.

[12] Eberhart, S.A and Russel, W.A,(1966). Stability parameters for comparing varieties, Crop Science Journal 6: pp 3640.

[13] Ekpe, E.O, Chinaka, C.C., Otto, E, Okoko, E.S and Emah, V.E (2005). Comparative evaluation of bubils and sett sizes on growth pattern and yieldof water yam (Dioscorea alata L). Nigerian Journal of Agriculture, Food and Environment 2 (1): 42 - 46

[14] FAO (1995) Food and Agricultural Organization. Production yearbook volume 26 and 29 FAO Rome.

[15] FAO, (1998) Food and Agriculture Organization. Production yearbook volume 27 and 28 FAO: Rome.

[16] Fogain, R.. S. Gowen and F. Mekemda, 1996. Evaluation of plantain s AAB and diploid AA, AB, and BB. Tropical Agriculture Trinidad 73: 281-285. 
Evaluation of the Progenies from a Cross between Obiaoturugo and Adaka for Evidence of Segregation for Morphological Attributes and Resistance to Major Field Diseases of White Yam (Dioscorea Rotundata Poir)

[17] IITA (1992) International Institute OF Tropical Agriculture. Annual Report of Root and Tuber Improvement Division. Ibadan, Nigeria.

[18] IITA (2008) International Institute of Tropical Agriculture. AGXE analysis provides vital insight for IITA crops. IITA Research p 12-29

[19] Jawahar, R.S.(2006) . Statistical and biometical techniques in Plant Breeding. New Age international $\mathrm{p}$ limited publishers $\mathrm{p} 5$

[20] Tropical Agriculture (Trinidad) Vol. $76 \mathrm{~N}^{\mathrm{O}} 3$ 97-105.

[21] Laurie, S.M., De villiers, R.P and Naude, S.P (1998). A strategy of sweet potato research focused on subsistence farmers in South Africa. South African J. of Science. 50: p341-451

[22] Moens, T., M. Araya and D. De Waele (2001). Correlations between nematode numbers and damage to banana (musa AAA) roots under commercial conditions. Nematropica 31 (1):55-65

[23] Ngeve J.M. (1999). Yield stability parameters for comparing cassava varieties. Proceedings of the $9^{\text {th }}$ symposium of ISTRC 20-26 $6^{\text {th }}$ October, 1991, Accra-Ghana. Research and Development Bulletin. 11 p9.

[24] Nwankwo, I.I.M, (2015). Variability in Tuber Yield, Flowering Intensity and Genetic Relationships Among Traits Of Intra-Specific Hybrids Of Dioscorea Rotundata (Poir). Ph.D. Thesis Presented to Department Of Agronomy, Michael Okpara University Of Agriculture Umudike

[25] Okoli , O.O (1984) Yam, Germplasm, Diversity Uses an prospects for crop improvement. Annual report of National Root Crops Research Institute, Umudike (1984) pp 111-117

[26] Okonkwo, S.N.C. (1985). The botany of the yam plant, and its exploitation in enhanced productivity of the crop. In Advances in yam research. The biochemistry and Technology of the yam tuber. G.C Osuji (ed). Biochemical Society of Nigeria and Anambrastate University of Technology, Enugu Nigeria pp $4-31$.

[27] Onwueme, I.C (1978). The Tropical tuber crops. Yam, Cassava, sweet potato, cocoyam. John Wiley and Sons. New York p. 234.

[28] Onwueme I.C. and Sinha T.D (1999). Field Crop production in Tropical Africa. Published by CTA Wageningen, Netherlands pp $250-258$. 